\section{Skal høyt blodtrykk ved akutt hjerneslag behandles?}

\author{
Blodtrykksbehandling med candesartan hadde ingen positive effekter \\ hos pasienter med akutt hjerneslag og høyt blodtrykk, ifølge en ny studie.
}

Høyt blodtrykk er vanlig hos pasienter med akutt hjerneslag og er forbundet med dårlig prognose. Flere dyreeksperimentelle studier og én klinisk studie har indikert at blodtrykkssenkende behandling med angiotensinreseptorblokkeren candesartan har positive effekter ved akutt hjerneslag.

Scandinavian Candesartan Acute Stroke Trial (SCAST) er en randomisert, placebokontrollert multisenterstudie av candesartan hos pasienter med akutt hjerneslag og systolisk blodtrykk $\geq 140 \mathrm{~mm} \mathrm{Hg}$ (1). Behandlingen ble startet innen 30 timer fra symptomdebut, og dosen med studiemedisin ble økt i løpet av de første tre dagene fra $4 \mathrm{mg}$ til $16 \mathrm{mg}$. Behandlingen ble gitt i til sammen sju dager. Oppfølgingstiden var seks måneder.

Studien hadde to primære effektvariabler: det kombinerte vaskulære endepunktet «vaskulært» dødsfall, hjerteinfarkt eller hjerneslag i løpet av de første seks måneder (analysert med Cox-regresjon) og funksjonsnivå ved seks måneder (målt med modifisert Rankin Scale).

2029 pasienter ble inkludert, og gruppene var sammenliknbare da behandlingen ble startet. $85 \%$ av pasientene hadde iskemisk hjerneslag og $14 \%$ hadde hemoragisk hjerneslag. Gjennomsnittlig blodtrykk var ca. 171/90 mm Hg i begge grupper, og behandlingen ble startet ca. 18 timer etter symptomdebut i begge.

- Det var en statistisk signifikant blodtrykksforskjell allerede på dag 2 etter at behandlingen var startet, og fra dag 4 til dag 7 så man en forskjell på $5 / 2 \mathrm{~mm} \mathrm{Hg}$. Det var imidlertid ingen signifikant forskjell mellom gruppene i risiko for det kombinerte vaskulære endepunkt. Etter seks måneder var det $ø$ kt risiko for dårligere funksjonsnivå i candesartangruppen, men forskjellen var ikke statistisk signifikant, sier doktorgradsstipendiat Else Charlotte Sandset og overlege Eivind Berge ved Oslo universitetssykehus.

- For alle sekundære endepunkter fant man også ikke-signifikante forskjeller i favør av placebo, og resultatene var de samme i alle prespesifiserte subgrupper. Vi gjorde også en metaanalyse av alle tidligere små studier av blodtrykkssenkende behandling ved akutt hjerneslag og fant at SCASTstudien bekreftet resultatet av denne.

Studien viste altså ingen positive effekter av blodtrykkssenkende behandling med candesartan i den akutte fasen av hjerneslag. Resultatene peker heller i retning av at slik behandling har skadelige effekter. Det pågår to andre studier som vil gi informasjon om hvorvidt resultatene fra SCAST-studien er generaliserbare eller om det finnes andre blod-

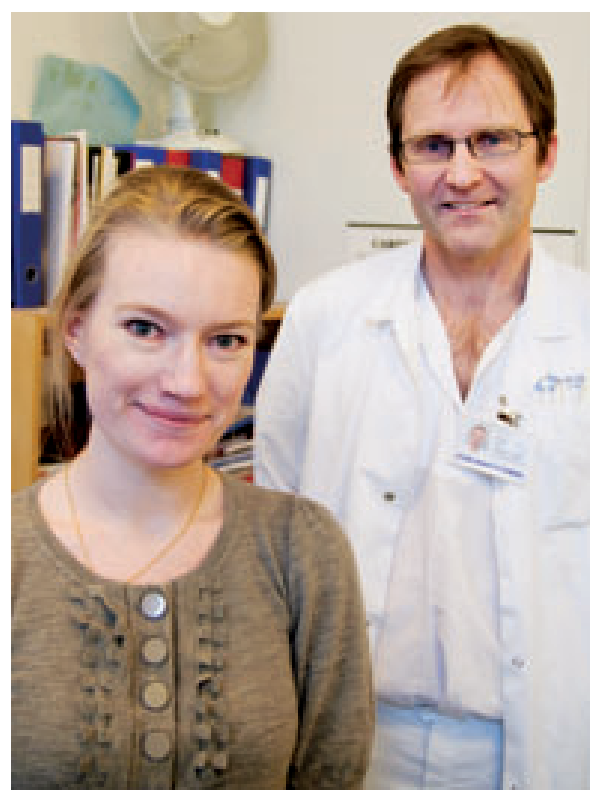

Else Charlotte Sandset og Eivind Berge. Foto Thea Tønnessen, Oslo universitetssykehus, Ullevål

trykkssenkende medisiner eller andre fremgangsmåter for senking av blodtrykket som kan ha positive effekter. Inntil disse studiene er avsluttet mener vi at blodtrykkssenkende behandling ikke skal gis rutinemessig til pasienter med forhøyet blodtrykk i den akutte fasen av hjerneslag, sier Sandset og Berge.

\section{Forskning på hjerneslag}

Studien har vært ledet av doktorgradsstipensitetssykehus, Ullevål. Prosjektansvarlig og koordinerende utprøver har vært overlege Eivind Berge ved Oslo universitetssykehus.

Sponsor for studien har vært Oslo universitetssykehus. Den har vært finansiert av Helse Sør-Øst og Oslo universitetssykehus, med frie, begrensede bevilgninger fra AstraZeneca og Takeda. AstraZeneca har også levert gratis medisiner til studien.

Studien ble startet i juni 2005, og siste pasient ble inkludert i februar 2010. Den omfattet 2029 pasienter ved 146 sykehus i ni land: Belgia, Danmark, Estland, Finland, Litauen, Norge, Polen, Sverige og Tyskland.

\section{Erlend Hem}

erlend.hem@medisin.uio.no

Tidsskriftet

\section{Litteratur}

1. Sandset EC, Bath PM, Boysen G et al. The angiotensin-receptor blocker candesartan for treatment of acute stroke (SCAST): a randomised, placebo-controlled, double-blind trial. Lancet 2011. DOI: 10.1016/S0140-6736(11)60104-9. diat Else Charlotte Sandset ved Oslo univer-

\section{Ordforklaringer}

Akutt hjerneslag og høyt blodtrykk: Nærmere $75 \%$ av pasienter med akutt hjerneslag har systolisk blodtrykk $\geq 140 \mathrm{~mm} \mathrm{Hg}$ når de innlegges i sykehus. Det finnes mange årsaker til dette: ubehandlet og inadekvat behandlet hypertensjon, stressrespons med aktivering av nevroendokrine systemer, ødeleggelse av sentre i hjernen som styrer blodtrykkskontrollen og økt intrakranialt trykk. Hos de fleste normaliseres blodtrykket i løpet av den første uken uten intervensjon (1).

Modifisert Rankin Scale (mRS): Modifisert Rankin Scale er en skala som går fra 0 til 6 . Den gir et globalt/helthetlig mål på pasienters funksjonsnivå. Skår 0 betyr fravær av symptomer, 5 betyr alvorlig svekket funksjonsnivå med behov for konstant pleie/ tilsyn. 6 betyr død.

\section{Litteratur \\ 1. Qureshi Al. Acute hypertensive response in patients with stroke: pathophysiology and management. Circulation 2008; 118: 176-87.}

\section{THE LANCET}

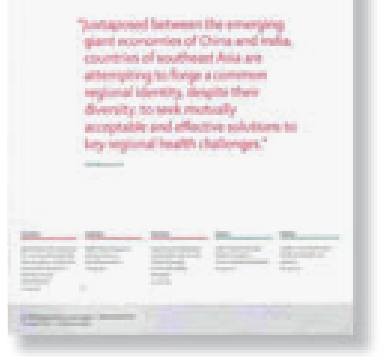

Artikkelen er publisert i The Lancet, som regnes som en av de «fem store» innen medisinsk publisering ved siden av New England Journal of Medicine, JAMA, Annals of Internal Medicine og BMJ. Publiseringsdatoer: på nett 11.2. 2011, på papir 26.2. 2011.

\section{Tips oss}

Er du i ferd med å publisere eller har du nylig publisert eller har du nylig publisert Send tips til erlend.hem@medisin.uio.no 